\title{
IMPLEMENTASI PENDIDIKAN MULTIKULTURAL DI MADRASAH INKLUSI \\ MADRASAH ALIYAH NEGERI MAGUWOHARJO YOGYAKARTA
}

\author{
Jiyanto dan Amirul Eko Efendi \\ IAIN Surakarta, Jawa Tengah, Indonesia \\ jiyanto89@yahoo.com
}

\begin{abstract}
THE IMPLEMENTATIONOF MULTICULTURAL EDUCATION IN INCLUSI ISLAMIC SCHOOL. Indonesia is a country that is made up of various ethnic groups, culture, ethnicity, and religion so that Indonesia can simply be referred to as a multicultural society. Nurcholish Madjid revealed that the plurality and multicultural is a rule of God (the laws) that can not be denied and anyone who tries to deny the law of cultural diversity, then there will be no end to the phenomenon of turbulence. Schools play an important role in instilling values in the multicultural students. If they have shared values, tolerance, love peace, and respect for differences, then these values will be reflected in the behavior of their everyday since formed on personality. If it is successfully held the young generation we, then the next life can be predicted to be relatively peaceful and respectful of others can be realized. Therefore, caring school teacher in this case is not only required in a professional implement multicultural values in a variety of opportunities that exist in schools in each subject, but they are also required to be able to instill the values of inclusive diversity to students.
\end{abstract}

Keywords: Implementation, Multicultural, Education. 


\section{Abstrak}

Indonesia adalah suatu negara yang terdiri dari berbagai kelompok etnis, budaya, suku, dan agama sehingga Indonesia secara sederhana dapat disebut sebagai masyarakat multikultural. Nurcholis Madjid mengungkapkan bahwa pluralitas dan multikultural adalah sebuab aturan Tuban (Sunnatullah) yang tidak dapat diingkari dan barang siapa yang mencoba mengingkari bukum kemajemukan budaya, maka akan timbul fenomena pergolakan yang tidak berkesudahan. Sekolah memegang peranan penting dalam menanamkan nilai multikultural pada siswa. Bila mereka memiliki nilai-nilai kebersamaan, toleran, cinta damai, dan mengbargai perbedaan, maka nilai-nilai tersebut akan tercermin pada tingkah laku mereka sehari-hari karena terbentuk. pada kepribadiannya. Bila bal tersebut berbasil dimiliki para generasi muda kita, maka kehidupan mendatang dapat diprediksi akan relatif damai dan penub penghargaan antara sesama dapat terwujud. Oleh karena itu, kepedulian sekolah dalam hal ini guru tidak hanya dituntut secara professional mengimplementasikan nilai-nilai multikultural dalam berbagai kesempatan yang ada di sekolah dalam setiap mata pelajaran, tetapi mereka juga dituntut untuk mampu menanamkan nilai-nilai keberagamaan yang inklusif kepada para siswa.

Kata kunci: Implementasi, Pendidikan Multikultural dan Madrasah

\section{A. Pendahuluan}

Indonesia adalah suatu negara yang terdiri dari berbagai kelompok etnis, budaya, suku, dan agama sehingga Indonesia secara sederhana dapat disebut sebagai masyarakat multikultural. Nurcholis Madjid mengungkapkan bahwa pluralitas dan multikultural adalah sebuah aturan Tuhan (Sunnatullah) yang tidak dapat diingkari dan barang siapa yang mencoba mengingkari hukum kemajemukan budaya, maka akan timbul fenomena pergolakan yang tidak berkesudahan. ${ }^{1}$ pendidikan bukan merupakan menara gading yang berusaha menjauhi realitas social dan budaya. Pendidikan menurutnya, harus mampu menciptakan

${ }^{1}$ Nurcholish Madjid, Islam Agama Peradaban, Membangun Makna dan Relevansi Doktrin Islam dalam Sejarah, (Jakarta: Paramadina, 1995), hlm. 56. 
tatanan masyarakat yang hanya mengagungkan prestise social sebagai akibat kekayaan dan kemakmuran yang dialaminya.

Istilah pendidikan multikultural dapat digunakan, baik pada tingkat deskriptif dan normatif yang menggambarkan isu-isu dan masalah-masalah pendidikan yang berkaitan dengan masyarakat multikultural. Lebih jauh juga mencakup pengertian tentang pertimbangan terhadap kebijakan-kebijakan dan strategistrategi pendidikan dalam masyarakat multikultural. Dalam konteks deskriptif, maka pendidikan multikultural seyogyanya berisikan tentang tema-tema mengenai toleransi, perbedaan ethnocultural dan agama, bahaya diskriminasi, penyelesaian konflik dan mediasi, hak asasi manusia, demokratisasi, pluralis, kemanusiaan universal, dan subjek-subjek lain yang relevan. ${ }^{2}$ Sejalan dengan itu, Musa Asy'arie mengemukakan bahwa pendidikan multikultural merupakan proses penanaman cara hidup menghormati, tulus dan toleran terhadap keragaman budaya yang hidup di tengahtengah masyarakat plural. ${ }^{3}$

Fenomena kemajemukan ini bagaikan pisau bermata dua, satu sisi memberi dampak positif, yaitu kita memiliki kekayaan khasanah budaya yang beragam, akan tetapi sisi lain juga dapat menimbulkan dampak negatif, karena terkadang justru keragaman ini dapat memicu konflik antar kelompok masyarakat yang pada gilirannya dapat menimbulkan instabilitas baik secara keamanan, sosial, politik maupun ekonomi. Dalam menghadapi pluralisme budaya tersebut, diperlukan paradigma baru yang lebih toleran dan elegan untuk mencegah dan memecahkan masalah benturan-benturan budaya tersebut, yaitu paradigma pendidikan multikultural. Hal ini penting untuk mengarahkan

${ }^{2}$ Muhaemin El-Ma'hady, Multikulturalisme dan Pendidikan Multikultural: Sebuah Kajian Awal (http://pendidikannetwork, 2004), hlm. 4. Lihat juga dalam Iis Arifudin, Urgensi Implementasi Pendidikan Multikultural di Sekolah,'Jurnal Insania, Pemikiran Alternatif Pendidikan, P3M STAIN Purwokerto, Vol. 12 No. 2 (MeiAgustus 2007), hlm. 3.

${ }^{3}$ H.A.R. Tilaar. Perubahan Sosial dan Pendidikan, Pengantar Pedagogike Tarnsformatif untuk Indonesia, (Jakarta: Gramedia, 2002), hlm. 5. 
anak didik dalam mensikapi realitas masyarakat yang beragam, sehingga mereka akan memiliki sikap apresiatif terhadap keragaman perbedaan tersebut. Bukti nyata tentang maraknya kerusuhan dan konflik yang berlatar belakang suku, adat, ras, dan agama menunjukkan bahwa pendidikan kita telah gagal dalam menciptakan kesadaran akan pentingnya multikulturalisme.

Pendidikan multikultural bertujuan untuk mengembangkan potensi yang dimiliki oleh peserta didik dan juga menciptakan keharmonisan dalam perbedaan. Bahwasanya manusia diciptakan oleh Tuhan masing-masing memiliki kelebihan dan kekurangan. Kendatipun demikian, adalah kewajiban manusia untuk mengembangkan apa yang telah diberikan Tuhan dan dalam hal ini lingkungan juga sangat berperan penting dalam membantu mengembangkan segala potensi individu maupun sosial. Sehingga gagasan pendidikan multikultural merupakan salah satu contoh bahwa lingkungan sangat berperan dalam pengembangan potensi manusia.

Sekolah memegang peranan penting dalam menanamkan nilai multikultural pada siswa. Bila mereka memiliki nilai-nilai kebersamaan, toleran, cinta damai, dan menghargai perbedaan, maka nilai-nilai tersebut akan tercermin pada tingkah laku mereka sehari-hari karena terbentuk pada kepribadiannya. Bila hal tersebut berhasil dimiliki para generasi muda kita, maka kehidupan mendatang dapat diprediksi akan relatif damai dan penuh penghargaan antara sesama dapat terwujud.

Oleh karena itu, kepedulian sekolah dalam hal ini guru tidak hanya dituntut secara professional mengimplementasikan nilai-nilai multikultural dalam berbagai kesempatan yang ada di sekolah dalam setiap mata pelajaran, tetapi mereka juga dituntut untuk mampu menanamkan nilai-nilai keberagamaan yang inklusif kepada para siswa.

Pembahasan implementasi pendidikan multikultural dalam pendidikan agama di Madrasah menjadi penting, mengingat pembahasan yang sifatnya operasional dan implementasinya yang 
masih langka. Bahasan umumnya bersifat wacana, pergeseran paradigma, maupun konsep teoritik semata. Dalam tulisan ini mencoba mengkaji implementasi pendidikan multikultural secara praktis di Madrasah. Adapun sistematika pembahasan dalam tulisan ini antara lain: bagaimana kajian tentang pendidikan multikultural, bagaimana pendidikan berbasis multikultural, bagaimana implementasi pendidikan multikultural di madrasah, bagaimana peran guru dan sekolah dalam pendidikan multikultural, dan bagaimana contoh implementasi pendidikan multikultural di MAN Maguwoharjo Yogyakarta.

\section{B. Pembahasan}

\section{Pengertian Pendidikan Multikultural}

Pendidikan multikultural dapat didefinisikan sebagai pendidikan untuk atau tentang keragaman kebudayaan dalam merespon perubahan demografis dan kultural lingkungan masyarakat tertentu bahkan dunia secara keseluruhan. Hal ini sejalan dengan pendapat Paulo Freire. ${ }^{4}$

Pendidikan multikultural adalah suatu pendekatan progresif untuk melakukan transformasi pendidikan yang secara menyeluruh membongkar kekurangan, kegagalan, dan praktikpraktik diskriminasi dalam proses pendidikan. ${ }^{5}$ Dengan demikian pendidikan multikultural, menurut Musa Asy'arie diharapkan adanya kekenyalan dan kelenturan mental bangsa menghadapi benturan konflik sosial.

\section{Konsep Dasar Pendidikan Multikultural}

Konsep pendidikan multikultural menjadi komitmen global sejalan dengan rekomendasi UNESCO, Oktober 1994 di Jenewa. Rekomendasi UNESCO tersebut memuat empat seruan: (a) pendidikan seyogyanya mengembangkan kesadaran untuk

\footnotetext{
${ }^{4}$ H.A.R. Tilaar. Perubaban Sosial dan Pendidikan, Pengantar Pedagogik Tarnsformatif untuk Indonesia, (Jakarta: Gramedia, 2002), hlm. 5.

${ }^{5}$ Ibid. hlm. 3
} 
memahami dan menerima sistem nilai dalam kebhinekaan pribadi, jenis kelamin, ras, etnik dan kultur; (b) pendidikan seyogyanya mendorong konvergensi gagasan yang memperkokoh perdamaian, persaudaraan, dan solidaritas dalam masyarakat; (c) pendidikan seyogyanya membangun kesadaran untuk menyelesaikan konflik secara damai; dan (d) pendidikan seyogyanya meningkatkan pengembangan kualitas toleransi dan kemauan untuk berbagi secara mendalam. ${ }^{6}$

Menurut H.A.R. Tilaar, pendidikan multikultural merupakan suatu wacana lintas batas. Dalam pendidikan multikultural, terkait masalah-masalah keadilan social (social justice), demokrasi, dan hak asasi manusia. Tidak mengherankan apabila pendidikan multikultural berkaitan dengan isu-isu politik, sosial, kultural, moral, edukasional dan agama. Tanpa kajian bidang-bidang ini maka sulit untuk diperoleh suatu pengertian mengenai pendidikan multikultural. Para pakar pendidikan mengidentifikasikan tiga lapis diskursus yang berkaitan dalam pendidikan multikultural:

a. Masalah kebudayaan. Dalam hal ini terkait masalah-masalah mengenai identitas budaya suatu kelompok masyarakat atau suku. Bagaimanakah hubungan antara kebudayaan dengan kekuasaan dalam masyarakat sehubungan dengan konsep kesetaraan di masyarakat.

b. Kebiasaan-kebiasaan. Tradisi, dan pola-pola kelakuan yang hidup di dalam suatu masyarakat.

c. Kegiatan atau kemajuan tertentu (achievement) dari kelompokkelompok dalam masyarakat yang merupakan identitas yang melekat pada kelompok di masyarakat yang merupakan identitas yang melekat pada kelompok tersebut. ${ }^{7}$

\footnotetext{
${ }^{6}$ Ibid. hlm. 4

${ }^{7}$ H.A.R. Tilaar. Perubahan Sosial dan Pendidikan, Pengantar Pedagogik Tarnsformatif untuk Indonesia, (Jakarta: Gramedia, 2002), hlm., 206.
} 


\section{Urgensi Pendidikan Multikultural di Indonesia}

Menurut Choirul Mahfud ${ }^{8}$ Pada dasarnya, model-model pembelajaran sebelumnya yang berkaitan dengan kebangsaan memang sudah ada. Namun, hal itu masih kurang memadai sebagai sarana pendidikan guna menghargai perbedaan masingmasing suku, budaya, etnis. Hal itu terlihat dengan munculnya konflik yang kerap terjadi pada realitas kehidupan berbangsa dan bernegara saat ini. Hal itu menunjukkan bahwa pemahaman toleransi masih amat kurang.

Menurut Stephen Hill dalam Choirul, ${ }^{9}$ paling tidak ada tiga hal penting dalam pendidikan multikultural di Indonesia, yaitu: pertama, pendidikan multikultural berfungsi sebagai sarana alternatif pemecahan konflik; kedua, dengan pendidikan multikultural, siswa tidak akan tercerabut dari akar budayanya; ketiga, pendidikan multikultural relevan di alam demokrasi seperti saat ini.

\section{a. Sebagai sarana alternatif pemecahan konflik}

Penyelenggaraan pendidikan multicultural didunia pendidkan diyakini dapat menjadi solusi nyata bagi konflik dan disharmonisasi yang terjadi di masyarakat, khususnya yang kerap terjadi di masyarakat Indonesia yang secara realitas plural. Dengan kata lain, pendidikan multikultural dapat menjadi sarana alternatif pemecahan konflik sosial budaya. ${ }^{10}$ pendidikan multikultural dapat dikatakan berhasil bila prosesnya melibatkan semua elemen masyarakat. Secara konkret, pendidikan ini tidak hanya melibatkan guru atau pemerintah saja, namun seluruh elemen masyarakat. Hal itu dikarenakan adanya multidemensi aspek kehidupan yang tercakup dalam pendidikan multikultural.

${ }^{8}$ Choirul Mahfud, Pendidikan Multikultural, (Yogyakarta: Pustaka Pelajar, 2006), hlm. 215.

${ }^{9}$ Ibid., hlm. 216.

${ }^{10}$ Ibid., hlm. 217. 


\section{b. Supaya siswa tidak tercerabut dari akar budaya}

Selain sebagai sarana alternatif pemecahan konflik, pendidikan multicultural juga signifikan dalam membina siswa agar tidak tercerabut dari akar budaya yang ia miliki sebelumnya, tatkala ia berhadapan dengan realitas sosial budaya di era globalisasi.

Dalam era globalisasi saat ini, pertemuan antarbudaya menjadi ancaman serius bagi anak didik. Untuk mensikapi realitas global tersebut, siswa hendaknya diberi penyadaran akan pengetahuan yang beragam, sehingga mereka memiliki kompetensi yang luas akan pengetahuan global, termasuk aspek kebudayaan. Mengingat beragamnya realitas kebudayaan di Negara ini, dan di luar negeri, siswa pada era globalisasi ini sudah tentu perlu diberi materi tentang pemahaman banyak budaya, atau pendidikan multikulturalisme, agar siswa tidak tercerabut dari akar budayanya itu. ${ }^{11}$ guru agama bukan sekedar penyampai materi pelajaran, tetapi lebih dari itu, ia adalah sumber inspirasi spiritual sekaligus sebagai pembimbing sehingga terjalin hubungan antara guru dan murid yang cukup dekat dan mampu melahirkan keterpaduan bimbingan ruhani dan akhlak dengan materi pengajarannya.

Begitu pula tentang mutu dan prestasi pendidikan agama harus diukur secara totalitas anak didik secara pribadi. Perilaku dan kesalehan yang ditampilkan dalam keseharian lebih penting dibandingkan dengan pencapaian nilai 9 (angka) atau A. Dalam hal ini menurut A. Malik dalam Ngainun, ${ }^{12}$

\section{c. Sebagai landasan pengembangan kurikulum nasional}

Dalam melakukan pengembangan kurikulum sebagai titik tolak dalam proses belajar mengajar, atau guna memberikan sejumlah materi dan isi pelajaran yang harus dikuasai oleh siswa dengan ukuran atau tingkatan tertentu. Pendidikan multikultural

\footnotetext{
${ }^{11}$ Ibid., hlm. 225

${ }^{12}$ Ngainun Naim dan Achmad Sauqi, Pendidikan Multikultural, hlm. 210.
} 
sebagai landasan pengembangan kurikulum menjadi sangat penting.

\section{Implementasi Pendidikan Multikultural di Madrasah}

Sebagai seorang guru agama, selain harus memiliki empat kompetensi seperti yang diamanatkan PP Nomor 19 tahun 2005 ia juga harus memiliki aspek lain yang membedakannya dengan guru bidang studi lainnya. Menurut Ngainun, ${ }^{13}$ mutu pencapaian pendidikan agama perlu diorientasikan kepada:

a. Tercapainya sasaran kualitas pribadi, baik sebagai muslim maupun sebagai manusia Indonesia.

b. Integrasi pendidikan agama dengan keseluruhan proses maupun institusi pendidikan yang lain.

c. Tercapainya internalisasi nilai-nilai dan norma-norma keagamaan.

d. Penyadaran pribadi akan tuntutan hari depannya dan transformasi sosial budaya yang terus berlangsung.

e. Pembentukan wawasan ijtihadiah (intelektual) di samping penyerapan pelajaran secara aktif.

Menurut H.A.R. Tilaar dalam Ngainun, ${ }^{14}$ paling tidak ada 4 nilai inti dalam pendidikan multikultural, yaitu:

a. Apresiasi terhadap adanya kenyataan pluralitas budaya dalam masyarakat.

b. Pengakuan terhadap harkat manusia dan hak asasi manusia.

c. Pengembangan tanggung jawab masyarakat dunia.

d. Pengembangan tanggung jawab manusia terhadap planet bumi.

Dalam kaitannya dengan proses pembelajaran agama, hal penting yang harus dipahami adalah karakteristik pendidikan multikultural. Pertama, belajar hidup dalam perbedaan. Pendidikan konvensional pada umumnya hanya bersandar pada tiga pilar

\footnotetext{
${ }^{13}$ Ibid., hlm. 211.

${ }^{14}$ Ibid., hlm. 213.
} 
utama yaitu: how to know, how to do, dan how to be, maka dalam pendidikan multikultural ditambah satu pilar lagi yakni: how to live and work together with others. Penanaman pilar ke empat sebagai suatu jalinan komplementer terhadap tiga pilar lainnya dalam praktik pendidikan meliputi proses:

a. Pengembangan sikap toleran, empati dan simpati

b. Membangun saling percaya

c. Memelihara saling pengertian (mutual understanding)

d. Menjunjung tinggi sikap saling menghargai

Selain aspek di atas, aspek lain yang harus mendapat perhatian adalah pendekatan dalam pembelajaran. Ada beberapa pendekatan yang dapat digunakan dalam pembelajaran agama Islam sehingga dapat menumbukan paham multikultural peserta didik, yaitu:

\section{a. Pendekatan Historis}

Pendekatan ini mengandaikan bahwa materi yang diajarkan kepada pembelajar dengan menengok kembali ke belakang. Maksudnya agar pebelajar dan pembelajar mempunyai kerangka berpikir yang komplit sampai ke belakang untuk kemudian mereflesikan untuk masa sekarang atau mendatang. Dengan demikian materi yang diajarkan bisa ditinjau secara kritis dan dinamis. Contoh dalam pembelajaran aqidah akhlak, dengan pendekatan ini bisa dikaji secara mendalam sampai ke akar- akarnya.

\section{b. Pendekatan Sosiologis}

Pendekatan ini mengandaikan terjadinya proses kontekstualisasi atas apa yang pernah terjadi di masa sebelumnya atau datangnya di masa lampau. Dengan pendekatan ini materi yang diajarkan bisa menjadi aktual, bukan karena dibuat-buat tetapi karena senantiasa sesuai dengan perkembangan zaman yang terjadi, dan tidak bersifat indoktrinisasi karena kerangka berpikir yang dibangun adalah kerangka berpikir kekinian. 
Pendekatan ini bisa digabungkan dengan metode kedua, yakni metode pengayaan.

\section{c. Pendekatan Kultural}

Pendekatan ini menitikberatkan kepada otentisitas dan tradisi yang berkembang. Dengan pendekatan ini pembelajar bisa melihat mana tradisi yang otentik dan mana yang tidak. Secara otolatis pebelajar juga bisa mengetahui mana tradisi arab dan mana tradisi yang datang dari islam.

\section{d. Pendekatan Psikologis}

Pedekatan ini berusaha memperhatikan situasi psikologis perseorangan secara tersendiri dan mandiri. Artinya masingmasing pembelajar harus dilihat sebagai manusia mandiri dan unik dengan karakter dan kemampuan yang dimilikinya. Pendekatan ini menuntut seorang pebelajar harus cerdas dan pandai melihat kecenderungan pembelajar sehingga ia bisa mengetahui metodemetode mana saja yang cocok untuk pembelajar.

\section{e. Pendekatan Estetik}

Pendekatan estetik pada dasarnya mengajarkan pembelajar untuk berlaku sopan dan santun, damai, ramah, dan mencintai keindahan. Sebab segala materi kalau hanya didekati secara doktrinal dan menekan adanya otoritas-otoritas kebenaran maka pembelajar akan cenderung bersikap kasar. Sehingga mereka memerlukan pendekatan ini untuk mengapresiasikan segala gejala yang terjadi di masyarakat dengan melihatnya sebagai bagian dari dinamika kehidupan yang bernilai seni dan estetis.

\section{f. Pendekatan Berprespektif Gender}

Pendekatan ini mecoba memberikan penyadaran kepada pembelajar untuk tidak membedakan jenis kelamin karena sebenarnya jenis kelamin bukanlah hal yang menghalangi seseorang untuk mencapai kesuksesan. Dengan pendekatan ini, segala bentuk konstruksi sosial yang ada di sekolah yang 
menyatakan bahwa perempuan berada di bawah laki-laki bisa dihilangkan. ${ }^{15}$

Keenam pendekatan ini sangat memungkinkan bagi terciptanya kesadaran multikultural di dalam pendidikan dan kebudayaan. Dan tentu saja, tidak menutup kemungkinan berbagai pendekatan yang lainnya, selain enam yang disebutkan tadi di atas, sangat mungkin untuk diterapkan.

\section{Implementasi Pendidikan Multikultural di MAN Maguwoharjo}

MAN Maguwoharjo Yogyakarta, dalam mengimplementasikan pendidikan multikultural, berbeda dengan sekolah lainnya. Karena konsep yang mendasari MAN Maguwoharjo adalah sekolah inklusif, sehingga tidak hanya mengajarkan dan mengimplementasikan pendidikan multikultural kepada semua siswanya, melainkan sekaligus mengimplementasikan dalam kehidupan sehari-hari di lingkungan sekolah. ${ }^{16}$

Sebagai sekolah inklusif, MAN Maguwoharjo melakukan penyesuaian pendidikan (adaptive education) terhadap perbedaanperbedaan siswanya secara efektif dan mengembangkan kemampuan mereka. Model pendidikan inklusif yang diterapkan di MAN Maguwoharjo adalah dengan melakukan penggabungan antara anak berkebutuhan khusus dengan anak normal. Yakni model kelas regular dengan pull out, anak berkelainan belajar bersama anak lain (normal) di kelas regular namun dalam waktu-waktu tertentu ditarik dari kelas regular ke ruang sumber untuk belajar dengan guru pembimbing khusus. Penggabungan ini merupakan konsep pendidikan inklusif, bahwa pendidikan itu untuk semua ABK juga memiliki hak utuk mendapatkan pendidikan, sehingga pembelajaran juga harus mengakomodasi mereka.

\footnotetext{
${ }^{15}$ Ibid., hlm. 215

${ }^{16}$ Wawancara dengan Kepala Sekolah MAN Maguwoharjo Yogyakarta, pada 3 November 2014.
} 
Dalam implementasi pendidikan multikultural, MAN Maguwoharjo menerapkannya baik di dalam kelas maupun di luar kelas. Berikut penjelasannya:

\section{a. Implementasi Pendidikan Multikultural di Dalam Kelas}

Penyelenggaraan pendidikan multikultural di sekolah inklusif menuntut adanya penyesuaian baik dari segi kurikulum, sarana dan prasarana pendidikan, maupun sistem pembelajaran yang disesuaikan dengan ABK yang ada di dalam sekolah inklusi. Namun, pendidikan multikultural tidak harus berdiri sendiri, tetapi dapat terintegrasi dalam mata pelajaran dan proses pendidikan yang ada di sekolah termasuk keteladanan para guru dan orangorang dewasa di sekolah. Seperti ditulis Azyumardi Azra, ${ }^{17}$ bahwa pengimplementasian pendidikan multikultural dapat diterapkan di sekolah dan masyarakat secara keseluruhan dengan cara memasukkan materi yang memiliki nilai multikultural.

Bentuk yang paling sederhana adalah menambahkan aspek multikultural ke dalam kurikulum yang standar. Oleh karena itu, pendidikan multikultural haruslah mencakup hal yang berkaitan dengan toleransi, perbedaan etno-kultural dan agama, bahaya diskriminasi, penyelesaian konflik dan mediasi, HAM, demokrasi dan pluralitas, kemanusiaan universal, dan subjek-subjek lain yang relevan mengantarkan terbentuknya masyarakat madani yang cinta perdamaian serta menghargai perbedaan. Isi dari pendidikan multikultural harus diimplementasikan berupa tindakan-tindakan, baik di sekolah maupun di masyarakat.

MAN Maguwoharjo, dalam memberikan pendidikan multikultural tidak hanya diberikan lewat teori, atau dengan menambahkan ke dalam kurikulum yang sudah ada, tetapi juga melalui praktik mengajar seperti disisipkan pada materi yang membahas masalah keberagaman, seperti IPS, Pendidikan Agama dan Pendidikan Kewarganegaraan.

${ }^{17}$ Azyumardi Azra, Pendidikan Islam: Tradisi dan Modernisasi Menuju Millinium Baru, (Jakarta: Penerbit Kalimah, 2001), hlm. 78-91. 
Pendidikan multikultural melalui pendidikan Kewarganegaraan dan pendidikan Agama serta pendidikan lainnya, harus dilakukan secara komprehensif. Dimulai dari desain perencanaan dan kurikulum melalui proses penyisipan, pengayaan dan atau penguatan terhadap berbagai kompetensi yang telah ada, mendesain proses proses pembelajaran yang bisa mengembangkan sikap siswa untuk bisa menghormati hak-hak orang lain, tanpa membedakan latar belakang ras, agama, bahasa dan budaya.

Dari aspek metode, strategi dan manajemen pembelajaran merupakan aspek penting dalam penerapan pendidikan multikultural, karena manajemen serta proses-proses pembelajaran merupakan praktik dan prosedur yang memungkinkan guru mengajar dan siswa belajar.

Dalam proses pembelajaran di sekolah inklusi MAN Maguwoharjo, banyak sekali materi serta proses pembelajaran yang memuat tentang nilai-nilai multikultural dan saling menghargai antara yang satu dengan yang lainnya, baik oleh siswa ataupun guru serta komponen lainnya.

Berikut beberapa bentuk metode serta strategi di MAN Maguwoharjo dalam proses pembelajaran yang mengandung nilai-nilai inklusif-multikultural:

\section{1) Cooperatif Learning}

Suatu strategi belajar mengajar yang menekankan pada sikap atau perilku bersama (team working) dalam bekerja atau membantu di antara semua dalam struktur kerjasama yang teratur dalam kelompok yang terdiri dari dua orang atau lebih. Dalam kelompok ini, siswa tidak dibedakan menurut kemampuan, karena disinilah siswa dilatih untuk peka terhadap perbedaan dan sikap saling menghargai perbedaan. ${ }^{18}$

${ }^{18}$ Dikutip dari Buku Panduan MAN Maguwoharjo dan wawancara dengan Kepala Sekolah MAN Maguwoharjo Yogyakarta, pada tanggal 7 November 2014. 
2) Incuiry Learning Approach

Proses pembelajaran yang di dorong oleh pertanyaan siswa yang menggerakkan pemahaman awal siswa ke tingkat yang lebih tinggi atau dalam. Metode ini merupakan proses pembelajaran agar siswa mampu berfikir kritis dalam melakukan penelitian sehingga memiliki pembelajaran yang reflektif. ${ }^{19}$

3) Active Learning

Pembelajaran aktif adalah segala bentuk pembelajaran yang memungkinkan siswa berperan secara aktif dalam proses pembelajaran itu sendiri baik dalam bentuk interaksi antar siswa maupun siswa dengan pengajar dalam proses pembelajaran tersebut. ${ }^{20}$

4) Teaching in Differentiation

Sebuah strategi pembelajaran yang merespon kebutuhan dan kemampuan siswa terutama untuk siswa yang berkebutuhan khusus (ABK), untuk memberikan dan memfasilitasi proses pembelajaran terbaik yang disesuaikan dengan kondisi dan potensi anak didik. ${ }^{21}$

5) IDU (Interdiciplinary Unit Programme)

Sebuah program interdisipliner, yakni program yang mengembangkan pendekatan cara belajar dengan membangun link atau hubungan antar mata pelajaran dan bidang studi. ${ }^{22}$

\section{b. Implementasi Pendidikan Multikultural di Luar Kelas}

Pendidikan multikultural di MAN Maguwoharjo, selain diimplementasikan ke dalam kurikulum, juga pengimplementasiannya dilakukan di luar sekolah. Pendidikan tidak hanya bersifat akademik saja, tetapi ada pula yang bersifat non akademik. Dalam
${ }^{19}$ Ibid.
${ }^{20} \mathrm{Ibid}$.
${ }^{21}$ Ibid.
${ }^{22}$ Ibid. 
lembaga pendidikan, pendidikan yang bersifat non akademik biasanya dimasukkan dalam ekstrakurikuler.

Kegiatan-kegiatan kesiswaan merupakan suatu wadah atau kegiatan-kegiatan yang positif agar siswa dapat menyalurkan bakat, minat ataupun kreatifitasnya pada kegiatan-kegiatan non akademik. Kegiatan ekstrakurikuler antara lain dalam bidang olah raga, seni, ilmu pengetahuan ataupun keagamaan. Kegiatankegiatan kesiswaan diantaranya adalah kegiatan intrakurikuler dan ekstrakurikuler.

Kegiatan intrakurikuler dan ekstrakurikuler dapat menumbuhkan nilai-nilai kebersamaan, kerukunan hidup serta menghargai keberadaan perbedaan yang ada. Setiap siswa memperoleh hak yang sama untuk memilih kegiatan ekstrakurikuler yang diminati tanpa memandang asal dan latar belakangnya. Di setiap kegiatankegiatan yang mengarah pada kebiasaan multikultur dengan sikap dan perilaku yang toleran antar teman, kebersamaan, solidaritas dan bisa saling bekerja sama dengan baik.

Adapun kegiatan intrakurikuler di MAN Maguwoharjo adalah sebagai berikut:

1) Lybrary visit

Merupakan kegiatan intrakurikuler MAN Maguwoharjo dengan mengajak siswa-siswanya melakukan kunjungan ke perpustkaan untuk mendukung tugas sekolah. Dalam kegiatan ini, siswa diberikan kebebasan untuk memilih buku sebagai penunjang kegiatan belajar.

Dalam kegiatan ini, siswa diajak semua ke perpustakaan sekolah, mereka diminta untuk membaca, disinilah proses memahami kepada diffabel, karena mereka belajar bersama dan saling menghargai serta mau menolong. Di dalam perpustakaan siswa normal dan siswa $\mathrm{ABK}$ saling membantu dalam menganalisa permasalahan memakai fasilitas buku-buku yang ada di perpustakaan. 
2) Studi Lapangan

Merupakan kegiatan intrakurikuler di MAN Maguwoharjo dengan mengajak langsung siswanya ke tempat-tempat yang dijadikan studi. Dalam kegiatan ini, baik siswa normal maupun yang ABK bersama sama seperti yang belum lama dilakukan adalah mengunjungi benteng Van der Wich dan Candi Sambisari.

\section{Simpulan}

Pendidikan multikultural merupakan proses penanaman nilai-nilai dan cara hidup menghormati, tulus, dan toleran terhadap keragaman budaya yang hidup di tengah-tengah masyarakat plural. Dengan pendidikan multikultural diharapkan adanya kekenyalan dan kelenturan mental bangsa menghadapi benturan konflik sosial.

Pendidikan multikultural tidak harus berdiri sendiri, tetapi dapat terintegrasi dalam mata pelajaran dan proses pendidikan yang ada di sekolah termasuk keteladanan para guru dan orangorang dewasa di sekolah. Isi dari pendidikan multikultural harus diimplementasikan berupa tindakan-tindakan, baik di sekolah maupun di masyarakat. Salah satu upaya untuk membangun kesadaran dan pemahaman generasi yang akan datang adalah dengan penerapan pendidikan multikultural. Hal ini dikarenakan pendidikan multikultural adalah proses penanaman cara hidup menghormati, tulus, dan toleran terhadap keanekaragaman budaya yang hidup di tengah-tengah masyarakat plural. 


\section{DAFTAR PUSTAKA}

Azra, Azyumardi, Pendidikan Islam: Tradisi dan Modernisasi Menuju Millinium Baru. Jakarta: Penerbit Kalimah. 2001.

Arifudin, Iis, Urgensi Implementasi Pendidikan Multikultural di Sekolah, 'Jurnal Insania, Pemikiran Alternatif Pendidikan, P3M STAIN Purwokerto, Vol. 12 No. 2 Mei-Agustus 2007.

Aly, Abdullah, Pendidikan Islam Multikultural di Pesantren: Telaah Terhadap Kurikulum Pondok Pesantren Modern Islam Assalam Surakarta, Yogyakarta: Pustaka Pelajar, 2011.

Andres Uhlin, Oposisi Berserak: Arus Deras Demokratisasi Gelombang III di Indonesia, terj. Rofik Subud, Bandung: Mizan, 1998.

Ahmad, Konsep Hak Asasi Manusia dalam Al-Qur'an: Dalam Islam dan Realitas Sosial di Mata Intelektual Muslim Indonesia, Amir Muhammad, Jakarta: Edu Indonesia Sinergi, 2005.

Akhmad Hidayatullah Al Arifin, "Implementasi Pendidikan Multikultural Dalam Praksis Pendidikan Di Indonesia”, Jurnal Pembangunan Pendidikan: Fondasi dan Aplikasi, Volume 1, Nomor 1, Juni, 2012

Mahfud, Choirul, Pendidikan Multikultural, Yogyakarta: Pustaka Pelajar, 2006.

Freire, Paulo, Politik Pendidikan: Kebudayaan, Kekuasaan, dan Pembebasan, Terj. Agung Priantoro, Yogyakarta: Pustaka Pelajar. 2002

H.A.R. Tilaar, Perubahan Sosial dan Pendidikan, Pengantar Pedagogik Tarnsformatif untuk Indonesia. Jakarta: Gramedia. 2002.

Muhaemin El-Ma'hady, Multikulturalisme dan Pendidikan Multikultural: Sebuah Kajian Awal http:/ / pendidikannetwork, 2004 
Mustaqim, Muhamad, "Upaya Integrasi Ilmu Islam dalam Menyelesaikan Problem Dikotomi Pendidikan”, Jurnal Penelitian, Volume 9, Nomor 2, Agustus 2015.

Naim, Ngainun dan Achmad Sauqi, Pendidikan Multikultural: Konsep dan Aplikasi. Yogyakarta: Ar-Ruzz Media. 2008

Madjid, Nurcholish, Islam Agama Peradaban, Membangun Makna dan Relevansi Doktrin Islam dalam Sejarah, Paramadina, Jakarta, 1995.

S. Hamid Hasan, Multikultural Untuk Penyempurnaan Kurikulum Nasional, Jurnal Pendidikan dan Kebudayaan. 026, 6.Oktober, 2000.

Syamsuddin, M. Etika Dalam Membangun Masyarakat Madani. Ciputat: Kalimah. 2000

Yakin, Ainul. Pendidikan Multikultural: Cross Cultural Understanding Untuk Demokrasi dan Keadilan, Yogyakarta: Pilar Media. 2005

Zamroni. Pendidikan Demokrasi pada Masyarakat Multikultural. Yogyakarta: Gavin Kalam Utama. 2011 
Jiyanto dan Amirul Eko Efendi

halaman ini bukan sengaja dikosongkan 